\title{
Antioxidant and Anticancer Properties of Metallo- porphyrins Embedded in Liposomes
}

\author{
Makoto Yuasa $^{1 *, 2}$, Kenichi Oyaizu², Hidenori Murata ${ }^{1}, Y^{2}$ oshizumi Sahara ${ }^{1}$, \\ Tomomi Hatsugai ${ }^{1}$ and Akihiko Ogata ${ }^{1}$ \\ ${ }^{1}$ Department of Pure and Applied Chemistry, Faculty of Science and Technology, Tokyo University of Science (Noda 278-8510, JAPAN) \\ ${ }^{2}$ Institute of Colloid and Interface Science, Tokyo University of Science (Tokyo 162-8601, JAPAN)
}

\begin{abstract}
Reactive oxygen species (ROS) are implicated in many disease such as inflammation, arteriosclerosis, cancer. Therefore, a water-soluble cationic metalloporphyrins with SOD activity are studied widely as antioxidant drugs. Further, liposomes are applied to drug delivery system (DDS) as drug carriers and investigated for example disposition and stability. We designed PEG modified liposomes for avoiding reticuloendothelial system (RES) and embedded cationic metalloporphyrins for DDS, evaluated antioxidant and anticancer property.

Preservation of these particle size measured DLS in an in vitro system, in order to simulate in vivo conditions of flow. Result of this measurement, we found Pluronic F-68/ liposomes have a long circulation property, and avoid fusion with plasma protein. SOD activity was determined by the stopped-flow analysis and cytochrome $\mathrm{c}$ assay, which allowed the evaluation of $\boldsymbol{k}_{\text {cat }}$ and $\mathrm{IC}_{50}$ for the reaction with a superoxide anion radical $\left(\cdot \mathrm{O}_{2}^{-}\right)$. Anti cancer property was measured by cell viability test. We found that $\mathrm{F}-68 /$ liposomes were the most effective catalyst as antioxidant and anticancer. These results revealed that porphyrin-embedded PEG-liposomes had the property of long circulation in blood and that this compound was effective as a SOD model compound with a drug carrier capacity.
\end{abstract}

Key words: superoxide anion radical, cationic metalloporphyrin, antioxidant, anticancer, PEG-Liposome

\section{1 緒言}

呼吸によって取り込まれた酸素の一部は, 反応性の 高い活性酸素種（スーパーオキシドアニオンラジカル $\left(\cdot \mathrm{O}_{2}^{-}\right)$, 過酸化水素 $\left(\mathrm{H}_{2} \mathrm{O}_{2}\right)$, ヒドロキシラジカル $(\mathrm{OH} \cdot))$ 一と変化する。 $\mathrm{O}_{2}^{-}$や $\mathrm{H}_{2} \mathrm{O}_{2}$ は, 体内に細菌や ウイルスが侵入した際，好中球やマクロファージなど の免疫細胞の生体防御 (殺菌や解毒作用), さらには紫 外線や放射線, 医薬, 大気污染よっても産出される。 このようにして発生した活性酸素種はそのほとんどが 生体内に存在する酵素（スーパーオキシドジスムター ゼ（SOD）, カタラーゼ，グルタチオンペルオキシター ゼ（GPX）など）により消去される。しかし恒常性 （活性酸素の消去と生成のバランス）が崩れて SOD な どの酵素活性が低下すると, 生体は酸化ストレス状態 になり炎症疾患・神経疾患・動脈硬化・癌・糖尿病等

\begin{abstract}
多くの病態に関与することが指摘されている
我々はこれまでに，生体内に存在する· $\mathrm{O}_{2}^{-}$を迅速に 消去する抗酸化㓱として, カチオン性金属ポルフィリ ン錯体, 特にマンガンポルフィリン錯体が· $\mathrm{O}_{2}^{-}$の不均 化反応を触媒 $\left(\cdot \mathrm{O}_{2}^{-}+\mathrm{Mn}^{3+}+2 \mathrm{H}^{+} \rightarrow \mathrm{H}_{2} \mathrm{O}_{2}+\mathrm{Mn}^{2+}\right)$ す るという有効な SOD 活性を示す一方，中心金属を鉄に 置き換えた同じカチオン性ポルフィリン錯体が, 癌細 胞内に過剩発生している· $\mathrm{O}_{2}^{-}$から不均化によって発生 する $\mathrm{H}_{2} \mathrm{O}_{2}$ をフェントン反応によって, より高い酸化力 に基づいて強い殺細胞性を示す $\mathrm{OH}$ ・変換する機構 $\left(\cdot \mathrm{O}_{2}^{-}+\mathrm{Fe}^{3+}+2 \mathrm{H}^{+} \rightarrow \mathrm{H}_{2} \mathrm{O}_{2}+\mathrm{Fe}^{2+} \rightarrow \mathrm{OH} \cdot+\mathrm{OH}^{-}+\right.$ $\mathrm{Fe}^{3+}$ ) により高い抗癌活性を示すということについて 明らかにしてきた 5 占)

そこでドラッグデリバリーシステム（DDS）構築を 目的として, 丸山らの研究7) を参考に, リポソーム表 面にポリエチレングリコール（PEG）鎖を導入するこ
\end{abstract}

\footnotetext{
* Correspondence to: Makoto Yuasa, Depertment of Pure and Applied Chemistry, Faculty of Science and Technology, Tokyo University of Science, 2641 Yamazaki, Noda, Chiba 278-8501, JAPAN

E-mail: yuasa@rs.noda.tus.ac.jp

Accepted October 7, 2006 (received for review March 20, 2006)
}

Journal of Oleo Science ISSN 1345-8957 print / ISSN 1347-3352 online

http://jos.jstage.jst.go.jp/en/ 
とで細網内皮系（Reticuloendothelial system: RES）へ の取り込みを回避し，血中安定性の向上が期待される PEG 修飾リポソームを設計し，これに高いSOD 活性 を示すマンガン打よび鉄 5,10,15,20-テトラキス（N-メチ ルピリジニウム-2-イル）ポルフィリンを包埋したポル フィリン / PEG 修飾リポソーム系についての抗酸化・ 抗癌活性について詳細に検討したので報告する。また， この系はその癌細胞選択性から現在臨床的に用いられ ている抗癌劑をあわせて封入することにより，より効 果的に癌治療ができる可能性がある。

\section{2 実験}

$2 \cdot 1$ 試 料

マンガン 5,10,15,20-テトラキス（N-メチルピリジニウ ム-2-イル）ポルフィリン (MnT2MPyP) および鉄 5,10,15,20-テトラキス（N-メチルピリジニゥム-2-イル） ポルフィリン（FeT2MPyP） は，既報8-13) により合成し た。リポソームの構成成分である脂質には, DMPC (ジミリストイルホスファチジルコリン)（日本油脂） を使用した。PEG 修飾化合物として, 疎水的なポリプ ロピレンオキシド鎖の両末端を親水性 PEG 鎖で修飾し たトリブロックコポリマーである非イオン性界面活性 剂のプルロニック F-68（旭電化）を用いた。脂質扎よ び PEG 化合物の濃度は合計で $200 \mu \mathrm{mol}$ になるように 調節した。リポソームの調製は超音波処理法を用いた。

\section{$2 \cdot 2 \mathrm{MT2MPyP/DMPC/Pluronic} \mathrm{F-68} \mathrm{リポソームの}$ 調製}

MnT2MPyP または FeT2MPyP $\left(1.0 \times 10^{-6} \mathrm{~mol}\right)$ を， ステアリン酸ナトリウム $(\mathrm{SA}-\mathrm{Na}) 1.2 \mathrm{mg}\left(4.0 \times 10^{-6}\right.$ mol）と, メタノール中で室温において覮拌（3 時間） することにより，ポルフィリンイオンコンプレックス （MnT2MPyP or FeT2MPyP：SA-Na＝1：4）を得た。 クロロホルムとメタノールの混合溶媒に溶解させた DMPC : プルロニック F-68 (=97:3, $95: 5,93: 7)$ 扎よびポルフィリンイオンコンプレックを遠沈管に 入れ，ロータリーエバポレーターにより溶媒を留去し

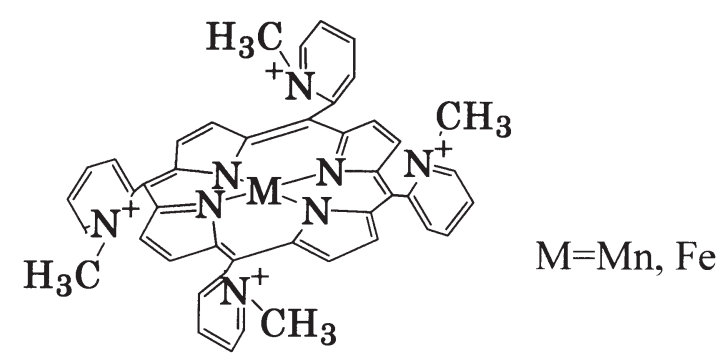

Fig. 1 Structure of MnT2MPyP and FeT2MPyP.
て遠沈管壁面に薄膜を形成した。次いで，水または生 理食塩水を $10 \mathrm{~mL}$ 加え, プローブ型ソニケーターに より超音波照射（水浴中, $20 \mathrm{~W}, 30 \mathrm{~min}$ )を行い MT2MPyP/DMPC/Pluronic F-68 リポソームを得た。

\section{$2 \cdot 3$ 測 定}

\section{$2 \cdot 3 \cdot 1$ リポソームの構造評価}

得られた MnT2MPyP / DMPC / Pluronic F-68 系の形 状打よび粒子径は, 透過型電子顕微鏡（TEM 観察） (H-7650, HITACHI), 動的光散乱法 (DLS 法) （NICOMP 380 ZLS）により評価した。リポソーム中の 金属ポルフィリン錯体の包埋状態は, 蛍光スペクトル 測定（SHIMADZU RF-5300PC）により調べた。測定は $25^{\circ} \mathrm{C}$ ，ポルフィリン濃度 $50 \mu \mathrm{M}$ で行った。常磁性 $\mathrm{Mn}$ および $\mathrm{Fe} イ$ インは消光因子となるため, 金属を導入し てない $\mathrm{H}_{2} \mathrm{~T} 2 \mathrm{MPyP}$ を別途に合成し，蛍光スペクトル測 定に供した。リポソーム二分子膜の膜流動性は，標識 分子に蛍光標識プローブに DPH（1,6-ジフェニル-1,3,5ヘキサトリエン）を用いて, 蛍光偏光解消法により評 価した。

$2 \cdot 3 \cdot 2$ リポソームの安定性評価

\section{$2 \cdot 3 \cdot 2 \cdot 1$ 擬似血中滞留試験}

生体投与を考慮し，より血中に近い条件での安定性 試験を行った。ペリスタポンプ（SJ1220（ATTO 社 製））で流動させながら（流速 $20 \mathrm{~mL} / \mathrm{min}$ ）, MnT2MPyP/DMPC/Pluronic F-68 系溶液にシェアスト レスをかけ，DLSによる粒子径の経時測定によりその 安定性を評価した。この際, 血液成分との相互作用や 凝集性を血清 (10\% FBS), アルブミン $(48 \mathrm{mg} / \mathrm{mL})$, フィブリノゲン $(3.8 \mathrm{mg} / \mathrm{mL})$ ，を用いて検討した ${ }^{14-16)}$ 。 アルブミン，フィブリノゲンは生体内濃度で調製した。 また，測定前は系内の滅菌作業としてエタノール，イ オン交換水，生理食塩水をそれぞれ 5〜10 分程度流し た。

\section{$2 \cdot 3 \cdot 3$ SOD 活性評価}

\section{$2 \cdot 3 \cdot 3 \cdot 1$ チトクローム c 法}

既報 ${ }^{17)}$ に基づく以下の方法により行った。SOD 活性

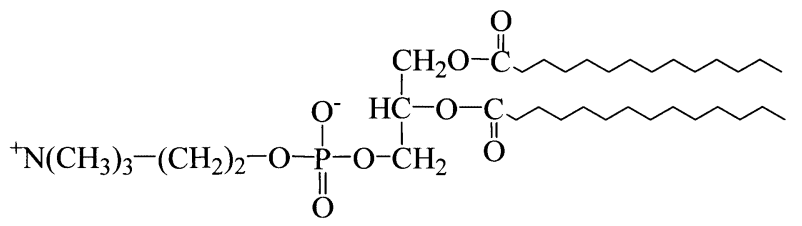

(a) DMPC

$$
\left(\mathrm{C}_{2} \mathrm{H}_{4} \mathrm{O}\right)_{\mathrm{n}}-\left(\mathrm{C}_{3} \mathrm{H}_{6} \mathrm{O}\right)_{\mathrm{m}}-\left(\mathrm{C}_{2} \mathrm{H}_{4} \mathrm{O}\right)_{\mathrm{n}}
$$

(b) Plurpnic F-68

Fig. 2 Structure of Lipid and PEG Derivative Compound. 
物質が存在しない条件下でのフェロチトクローム c $\left(\lambda_{\max }=550 \mathrm{~nm}\right)$ の吸光度の経時変化を測定し，その傾 きから阻害率 $0 \%$ に相当する值（ $a_{0} ）$ を得た。次に各濃 度のポルフィリン錯体存在下に打いて, 吸光度変化 $\left(\mathrm{a}_{1}\right)$ をそれぞれ求めた。SOD 活性物質の存在下で は， $\mathrm{O}_{2}^{-}$が消費されフェロチトクローム $\mathrm{c}$ の生成速度 が減少することにより，[1] 式より阻害率 I（\%) を求 めた。

阻害率 $\mathrm{I}(\%)=\left(\mathrm{a}_{0}-\mathrm{a}_{1}\right) / \mathrm{a}_{0} \times 100$

\section{$2 \cdot 3 \cdot 3 \cdot 2$ ストップトフロー法}

ストップトフロー法による評価は，既報 ${ }^{18)} に$ 基づき 以下の方法で行った。混合装置にはUNISOKU 製自動 コック付きミキシング装置を用いた。混合装置のシリ ンダーAに HEPES 緩衝溶液を用いて調製したSOD 活 性物質溶液を入れ, シリンダー B に超酸化カリウム（1 g）をDMSO に分散させて調製した· $\mathrm{O}_{2}^{-}$飽和溶液を入 れた。シリンダーA 打よび B 内の溶液を体積比 $20: 1$ で迅速に混合した後, $270 \mathrm{~nm}$ における吸光度の経時変 化を測定した。

\section{$2 \cdot 3 \cdot 4$ 抗癌活性評価}

マウスの肺癌細胞 (Lewis Lung Carcinoma (LLC)) を $\mathrm{DMEM}+10 \% \mathrm{FBS}$ 培地により，5\% $\mathrm{CO}_{2}$ 下で培養 した。この LLC 細胞を 96 ウェルマイクロプレートに $\left(1 \times 10^{4}\right.$ cells / well $)$ まき, 抗癌戍として用いる, ポル フィリン/リポソーム $(100 \mu \mathrm{L} /$ well $)$ ，を加え，Alamar Blue Assay 法 ${ }^{19)}$ により, 評価した。吸光度は $570 \mathrm{~nm}$ および $600 \mathrm{~nm}$ の二波長で測定し，生存率を算出した。

\section{3 結果および考察}

\section{$3 \cdot 1$ リポソームの構造評価}

\section{$3 \cdot 1 \cdot 1$ 動的光散乱測定}

DLS ヒストグラム（Fig. 3）およびTable 1より， MnT2MPyP/DMPC/Pluronic F-68 リポソームは粒子径 が約 40 〜 $50 \mathrm{~nm}$ であることがわかった。これらのよう な 40 ～ $50 \mathrm{~nm}$ 径のリポソームは小さな 1 枚膜リポソー ム SUV（Small Unilamellar Vesicle）であると考えられ る。

Fig. 3, Table 1 より, MnT2MPyP/DMPC/Pluronic F-68 はどの組成に打いても粒子径が約 30 ～ $50 \mathrm{~nm}$ で あった。ドラッグデリバリーシステム（DDS）を構築 するためにリポソーム粒子径を約 $100 \mathrm{~nm}$ 以下にするこ とで細網内皮系 (RES) への取り込みを回避し, 血中 滞留性の向上が見込まれるという報告がある ${ }^{20)}$ 。土田 らによるリポソーム包埋へムの微小粒子（粒径 $40 \mathrm{~nm}$ ) では, 血液成分との相互作用が少なく血液適合性が良
好（溶血，凝固，血小板凝集がない）で，物理化学的 特性, 酸素輸送能, 生理特性に優れた性質が観測され て扔り，ラットでの血中滞留時間も 14〜20 時間と適当 であると報告されている ${ }^{21)}$ 。また抗癌剤の機能として， 癌組織付近に存在する新生血管の細孔を通過するため のサイズコントロールとしてリポソーム粒子径を約 100 $\mathrm{nm}$ 以下にすることが望まれている（EPR（Enhanced Permeability and Retention) 効果 $\left.{ }^{7)}\right)$ 。このことからも MnT2MPyP/DMPC/Pluronic F-68 では薬郕として有効 な粒子径であることが明らかとなった。

$3 \cdot 1 \cdot 2$ 透過型電子顕微鏡測定

既報5,6) に示されるように，DMPCのみで調製したポ ルフィリン/リポソームの粒子径は打よそ $20 \mathrm{~nm}$ ～ 50 nmの SUVであることがわかっている。

Fig. 4 より, MnT2MPyP/DMPC/Pluronic F-68 系で は Pluronic F-68 濃度が DMPC に対して 3\%〜 7\%の組 成で打よそ $50 \mathrm{~nm} \sim 100 \mathrm{~nm}$ 程度の球状粒子の形成が確 認された。

\section{$3 \cdot 1 \cdot 3$ 蛍光スペクトル測定}

Fig. 5 より, 極性の高い環境である $\mathrm{H}_{2} \mathrm{~T} 2 \mathrm{MPyP} /$ waterの $\lambda_{\mathrm{em}, \max }(638 \mathrm{~nm})$ に比べ, 低極性である $\mathrm{H}_{2} \mathrm{~T} 2 \mathrm{MPyP} / \mathrm{MeOH}$ の $\lambda_{\mathrm{em}, \max }$ は $644 \mathrm{~nm}$ と長波長側にシ フトしていることが分かる。 MnT2MPyP / DMPC / Pluronic F-68 系では $\lambda_{\mathrm{em}, \max }$ は $640 \mathrm{~nm} \sim 642 \mathrm{~nm}$ と水打 よびメタノール溶媒に打ける $\lambda_{\mathrm{em}, \max }$ の間の值をとって

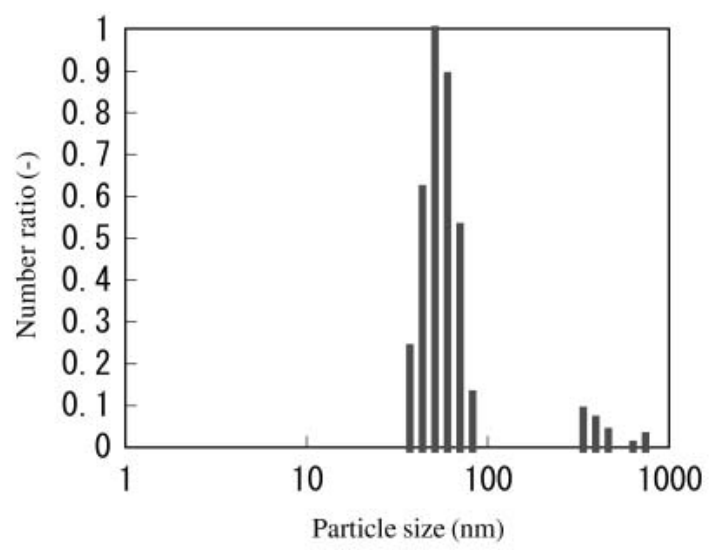

Fig. 3 DLS Histogram for the Particle Size of MnT2MPyP/ DMPC/Pluronic F68 (97:3).

Table 1 Number-Averaged Particle Size of MnT2MPyP/ DMPC/Pluronic F68.

\begin{tabular}{lc}
\hline MnT2MPyP/lipid/PEG compound (mole ratio) & Particle size (nm) \\
\hline MnT2MPyP/DMPC/Pluronic F-68 $(97: 3)$ & 53.6 \\
MnT2MPyP/DMPC/Pluronic F-68 $(95: 5)$ & 46.6 \\
MnT2MPyP/DMPC/Pluronic F-68 $(93: 7)$ & 50.8 \\
\hline
\end{tabular}




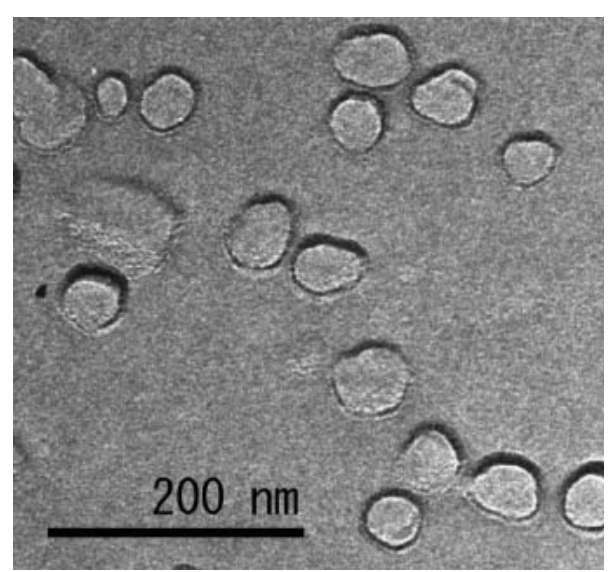

Fig. 4 TEM Picture of MnT2MPyP/DMPC/ Pluronic F68 (97: 3).

いる。これらの結果より $\mathrm{H}_{2} \mathrm{~T} 2 \mathrm{MPyP}$ はリポソームの外 水相, または内水相に存在するのではなく二分子膜の 親水, 疎水境界付近に存在することが考えられる。

$3 \cdot 1 \cdot 4$ 蛍光偏光解消測定

Fig. 6 からわかるように, MnT2MPyP / DMPC / Pluronic F-68 系におけるゲルー液晶転移は一段階で起 きている。二分子膜中に扔いて, DMPC 成分と PEG 化 合物成分が局在化し，相分離状態にあると仮定すると， 相転移に伴う蛍光編光度の挙動は二段階, もしくはそ

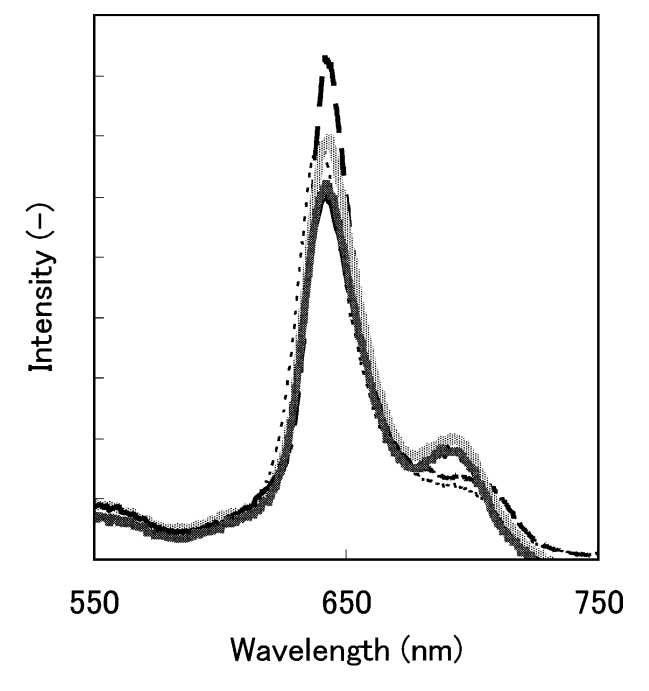

-.... H2T2MPyP / water

- - $\mathrm{H} 2 \mathrm{~T} 2 \mathrm{MPyP} / \mathrm{MeOH}$

H2T2MPyP / DMPC : pluronic $=97: 3 /$ water

- H2T2MPyP / DMPC : pluronic $=95: 5 /$ water

- H2T2MPyP / DMPC : pluronic $=93: 7 /$ water

Fig. 5 Fluorescence Spectra.
Table 2 Phase Transition Temperature.

\begin{tabular}{ll}
\hline \multicolumn{1}{c}{ Substrates } & $\mathrm{T} c\left({ }^{\circ} \mathrm{C}\right)$ \\
\hline MnT2MPyP/DMPC & 23 \\
MnT2MPyP/DMPC/Pluronic F-68 (97: 3) & 25.5 \\
MnT2MPyP/DMPC/Pluronic F-68 (95: 5) & 27 \\
MnT2MPyP/DMPC/Pluronic F-68 (93: 7) & 28 \\
Pluronic F-68 & 35 \\
\hline
\end{tabular}

れ以上になることが予想される。したがってこの結果 から DMPC と混合した Pluronic F-68 分子は相分離する ことなく均一系であることがわかる。また, Table 2 よ り, MnT2MPyP / DMPC / Pluronic F-68 系において DMPC に対する Pluronic F-68 の濃度が $3-7 \%$ と増加 するに従い， $\mathrm{T} c$ も増加する傾向にあることがわかっ た。これは, Pluronic F-68 分子が二分子膜中に導入さ れることにより, 分子同士が密になりリポソーム膜が より硬くなったことが考えられる。

動的光散乱, 蛍光スペクトル, 蛍光偏光解消測定の 結果と既報22-24) に示される膜モデルと類似した構造で あることから，MT2MPyP/DMPC/Pluronic F-68 系の 膜構造モデルを Fig. 7 のようになっていると考えられ る。

\section{$3 \cdot 2$ リポソームの安定性評価}

$3 \cdot 2 \cdot 1$ 擬似血中滞留試験

Fig. 8 に示すように, MnT2MPyP/DMPC/Pluronic F-68 系では, 血清, アルブミン，フィブリノーゲンと の血液成分に扔いても相互作用は見られず，血中での 長期安定性が期待できる結果となった。

MnT2MPyP/DMPC/Pluronic F-68 系の安定性が顕著 に高かった理由として，まず，ポルフィリン/リポソー ムの表面に存在する親水性高分子である PEG 鎖がリポ

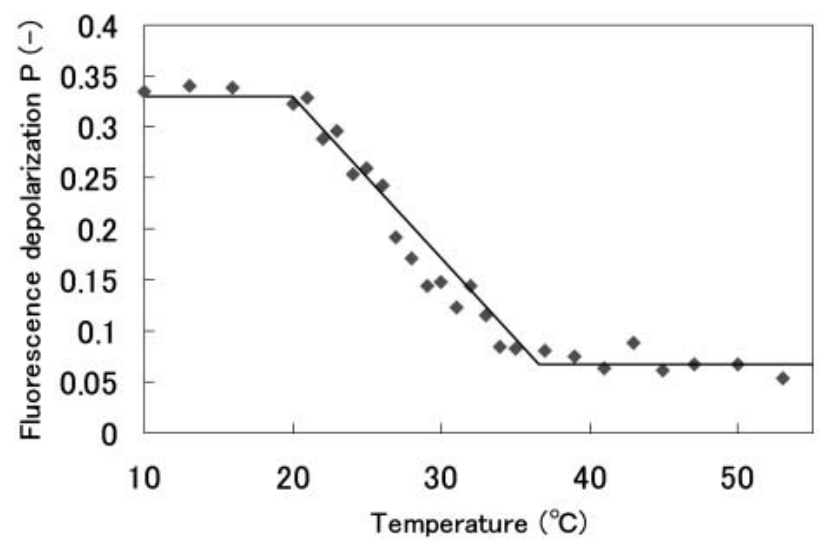

Fig. 6 MnT2MPyP/DMPC/Pluronic F-68 (93: 7) by Fluorescence Depolarization Method. 


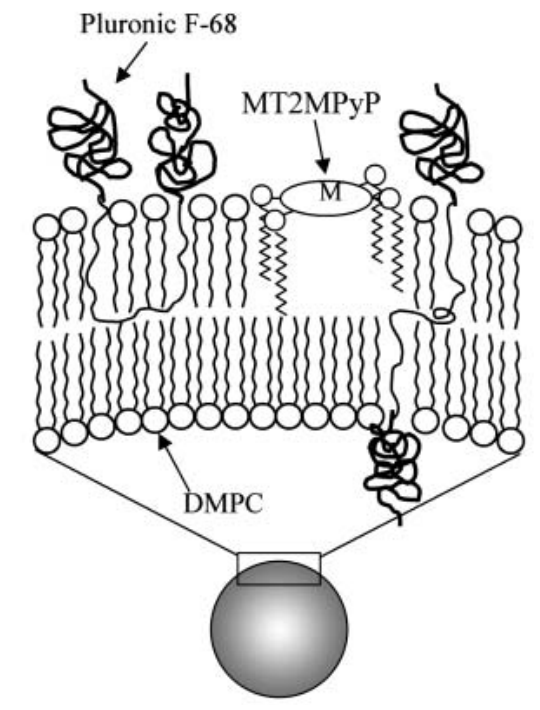

Fig. 7 Membrane Structure Model of MT2MPyP/DMPC/ Pluronic F-68.

ソーム表面で水和層を形成し，アルブミンなどの踈水 的なたんぱく質や血液成分との融合を回避したことが 考えられる。また，長鎖 PEGによるリポソーム同士の 融合が立体的に回避されたこと, 血清成分の吸着が立 体的に阻害されたことが考えられる。このことから MnT2MPyP/DMPC/Pluronic F-68 系は血中投与の際の 有効なドラッグキャリヤーとして期待できる。

\section{3·3 SOD 活性評価}

Table 3 に各種 SOD モデル化合物のチトクローム $c$ 法およびストップトフロー法による SOD 活性の測定結 果を示す。MnT2MPyP / DMPC / Pluronic F-68 では, PEG 鎖の立体障害による活性低下が予想されたが， $\mathrm{IC}_{50}, k_{\text {cat }}$ ともに MnT2MPyP, MnT2MPyP/DMPC と 同様の活性が得られた。MnT2MPyP/DMPC/Pluronic F-68 系の SOD 活性が低下しない理由として, 粒子径 $25 \mathrm{~nm}$ のリポソーム表面に Pluronic F-68 を密に被覆し たときの DMPC に対する Pluronic F-68 の含有率（約

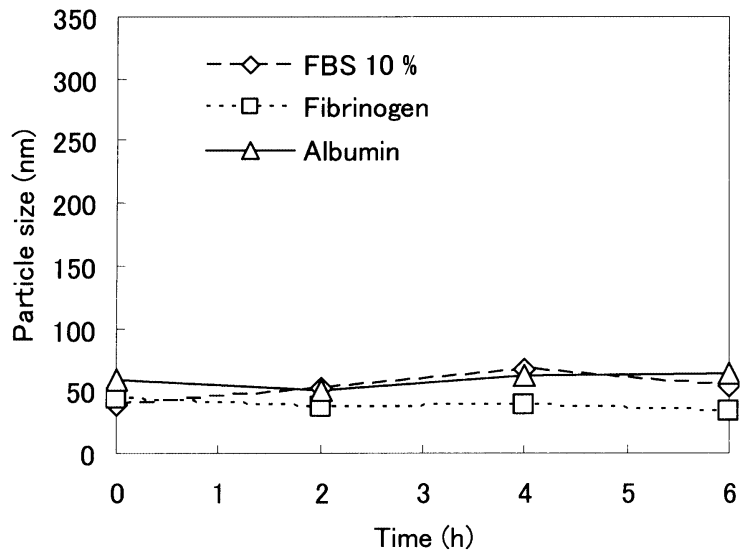

Fig. 8 Influence of Blood Component for MnT2MPyP/ DMPC/Pluronic F-68 (97: 3).

8.2\%)に対して，今回設計したリポソームが Pluronic F-68 の含有率 3〜 7\%とリポソーム表面を密に覆うこと なく $\mathrm{PEG}$ 鎖が存在しているためであると考えられる。

さらに, MnT2MPyP/DMPC/Pluronic F-68 系では, MnT2MPyP がリポソーム表面近傍に存在することでカ チオン基による静電的な $\mathrm{O}_{2}^{-}$の引き込みが因子となる ことから，高いSOD 活性を示したものと考えられ，血 中滞留性有する優れた SOD 化合物になりうると期待さ れる。

\section{$3 \cdot 4$ 抗癌活性}

Fig. 9 に FeT2MPyP, 各リポソーム系における LLC 細胞試験の結果を示す。DMPC 単独系, DMPC / Pluronic F-68単独系の細胞毒性はなかった。 FeT2MPyP / DMPC 系, FeT2MPyP / DMPC / Pluronic F-68 系の結果より，リポソームに包埋することによる 殺細胞性の低下はみられなかった。細胞試験の結果か ら，臨床的に用いられているシスプラチン (CDDP) と比較して, FeT2MPyP/DMPC/Pluronic F-68 系は優 れた抗癌活性を示すことが明らかとなった。 FeT2MPyP / DMPC / Pluronic F-68 系が特に活性が高

Table 3 Result of Cytchrome c Assay (IC50) and Stopped-Flow Analysis ( $k_{\text {cat }}$ ).

\begin{tabular}{lccc}
\hline \multicolumn{1}{c}{ Substrates } & IC50 $(\mu \mathrm{M})$ & $k_{\text {cat }}\left(\mathrm{M}^{-1} \mathrm{~s}^{-1}\right)$ & Ref. \\
\hline MnT2MPyP & 0.23 & $7.6 \times 10^{7}$ & This work \\
MnT2MPyP/DMPC & 0.20 & $6.2 \times 10^{7}$ & " \\
MnT2MPyP/DMPC/Pluronic F-68 (97: 3) & 0.077 & $9.4 \times 10^{7}$ & " \\
MnT2MPyP/DMPC/Pluronic F-68 (95: 5) & 0.096 & $8.2 \times 10^{7}$ & " \\
MnT2MPyP/DMPC/Pluronic F-68 (93: 7) & 0.12 & $8.2 \times 10^{7}$ & " \\
\hline \hline Cu-Zn/SOD & - & $2.3 \times 10^{9}$ & 25 \\
SMA-MnMPyP & - & $2.8 \times 10^{6}$ & " \\
\hline
\end{tabular}




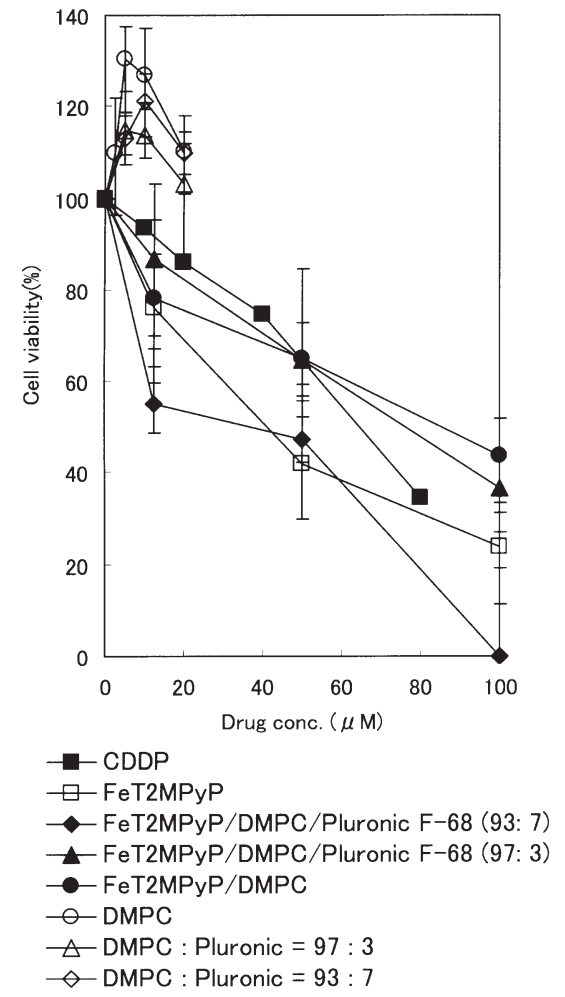

Fig. 9 Cell Viability Test of LLC Tumor Cells by Evaluated Alamar Blue Assay.

かった理由として, リポソーム表面 PEG 鎖により培地 との相互作用が少なく, 安定性を保持し細胞内に取り 込まれたこと，細胞との親和性が高かったことなどが 考えられる。さらに FeT2MPyP は癌細胞内で特異的に 多量に存在している· $\mathrm{O}_{2}^{-}$をターゲットとした抗癌機構 であるので, 正常細胞への毒性（副作用）が少ない抗 癌剂としてはたらくことが予想される ${ }^{6)}$ 。以上の結果よ り, FeT2MPyP / DMPC / Pluronic F-68 系は長期血中滞 留型の抗癌剤として期待される。

\section{4 結 論}

抗酸化・抗癌活性化合物としてマンガンおよび鉄 5,10,15,20-テトラキス（N-メチルピリジニウム-2-イル） ポルフィリンを合成し, PEG 鎖を有するリポソームに 包埋した結果，次の結論を得た。

FeT2MPyP/DMPC / Pluronic F-68 系は生体投与の際 RES への取り込みを回避し, 長期血中安定性が期待で きる約 40 〜 $50 \mathrm{~nm}$ であった。ポルフィリンはリポソー 厶二分子膜の親水・疎水界面に存在に存在しているこ とが確認された。

安定性試験結果より, MnT2MPyP/DMPC/Pluronic F-68 系はリポソーム表面 PEG 鎖の親水層の形成, およ
び立体効果による血液成分との相互作用，リポソーム 同士の融合が顕著に抑制された。

SOD 活性評価より, MnT2MPyP / DMPC / Pluronic F-68 系に扎いても MnT2MPyP 単独系と同様に高い活 性を維持した。

細胞試験より, FeT2MPyP/DMPC/Pluronic F-68 系 が有効な抗癌効果を示した。

以上より，MT2MPyP/DMPC/Pluronic F-68 系は長 期血中滞留性が見込まれる抗酸化・抗癌剮となりうる。

\section{References}

1. Faulkner, K.M.; Liochev, S.I.; Fridovich, I. Stable Mn(III) porphyrins mimic superoxide dismutase in vitro and substitute for it in vivo. J. Biol. Chem. 269, 23471-23476 (1994).

2. H. KAWAKAMI, Control of reactive oxygen species by water-soluble cationic metalloporphyrin, Oleoscience. Vol. 1, 157-166 (2001).

3. Krishna, M.C.; Degraff, W.; Tamura, S.; Gonzalez, F.J.; Samuni, A.; Russo, A.; Mitchell, J.B. Mechanisms of hypoxic and aerobic cytotoxicity of mitomycin $\mathrm{C}$ in chinese hamster V79 Cells. Cancer Res. 51, 6622-6628 (1991).

4. Tisdale, M.J.; Mahmoud, M.B. Activities of free radical metabolizing enzymes in tumours. Br. J. Cancer. 47, 809-812 (1983).

5. Yuasa, M.; Oyaizu, K.; Ogata, A.; Matsukura, N.; Yamaguchi, A. Preparation of liposomes surface-loaded with cationic manganese porphyrins as SOD mimics. J. Oleo Sci. 54, 233-239 (2005).

6. Yuasa, M.; Oyaizu, K.; Horiuchi, A.; Ogata, A.; Hatsugai, T.; Yamaguchi, A.; Kawakami, H. Liposomal surfaceloading of water-soluble cationic iron(III) porphyrins as anticancer drugs. Mol. Pharm. 1, 387-389 (2004).

7. Kasaoka, S.; Maruyama, K Application of functionalazed liposomal membrane to DDS development. $J$. Oleo Sci. 2, 189-195 (2002).

8. Adler, A.D.; Longo, F.R.; Goldmacher, J.F.J.; Assour, J.; Kosakoff, L. A simplified synthesis for mesotetraphenylporphine. J. Org. Chem. 32, 476 -476 (1967).

9. Kalyanasundaram, K. Photochemistry of water-soluble porphyrins: comparative study of isomeric tetrapyridyland tetrakis $(N$-methylpyridiniumyl)porphyrins. Inorg. Chem. 23, 2453-2459 (1984).

10. Adler, A.D.; Longo, F.R.; Varadi, V. Preparation of metalloporphyrins. Inorg. Synth. 16, 213-220 (1976).

11. Hambright, P.; Gore, T.; Burton, M. Synthesis and characterization of new isomeric water-soluble porphyrins. Tetra(2-N-methylpyridyl)porphine and tetra $(3-N$ methylpyridyl)porphine. Inorg. Chem. 15, 2314-2315 (1976).

12. Harriman, A.; Porter, G. Photochemistry of manganese porphyrins. J. Chem. Soc. Faraday. Trans. II. 75, 
1532-1542 (1979).

13. Hunt, J.A.; Lee, J.; Groves, J.T. Amphiphilic peroxynitrite decomposition catalysts in liposomal assemblies. Chem. Biol. 4, 845-858 (1997).

14. Sudimack, J.J.; Guo, W.; Tjarks, W.; Lee, R.J. A novel $\mathrm{pH}$-sensitive liposome formulation containing oleyl alcohol. Biochim. Biophys. Acta. 1564, 31-37 (2002).

15. Nicolazzi, C.; Mignet, N.; Figuera, N.D.L.; Cadet, M.; Ibad, R.T.; Seguin, J.; Scherman, D.; Bessodes, M. Anionic polyethyleneglycol lipids added to cationic lipoplexes increase their plasmatic circulation time. $J$. Cont. Rel. 88, 429-443 (2003).

16. Kim, J.-K.; Choi, S.-H.; Kim, C.-O.; Park, J.-S.; Ahn, W.S.; Kim, C.-K. Enhancement of polyethylene glycol (PEG)-modified cationic liposome-mediated gene deliveries: Effects on serum stability and transfection efficiency. J. Pham. Pharmacol. 55, 453-460 (2003).

17. Mccord, J.M.; Fridovich, I. Superoxide dismutase. An enzymic function for erythrocuprein (Hemocuprein). $J$. Biol. Chem. 244, 6049-6055 (1969).

18. Riley, D.P.; Rivers, W.J.; Weiss, R.H. Stopped-flow kinetic analysis for monitoring superoxide decay in aqueous systems. Biochemistry. 196, 344-349 (1991).

19. Nakayama, G.R.; Caton, M.C.; Nova, M.P.; Parandoosh, Z. Assessment of the alamar blue assay for cellular growth and viability in vitro. J. Immunol. Methods.
204, 205-208 (1997).

20. Gregory, G.; Christopher, K.; Judith, S. Optimization of liposome behavior in vivo. Biol. Cell. 47, 11-18 (1983).

21. Matsushita, Y.; Eshima, K.; Shindo, T.; Yamamoto, Y.; Hasegawa, E.; Nishide, H.; Tsuchida, E. Clearance and tissue distribution of functionalized polymeric liposomes from the blood stream of rats. Biochim. Biophys. Acta. 901, 166-171 (1987).

22. Schillen, K.; Bryskhe, K.; Mel'ikova, Y.S. Vesicles formed from a poly(ethylene oxide)-poly(propylene oxide)-poly(ethylene oxide) triblock copolymer in dilute aqueous Solution. Macromolecules. 32, 6885-6888 (1999).

23. Varshney, M.; Morey, T.E.; Shah, D.O.; Filint, J.A.; Moudgil, B.M.; Seubert, C.N.; Dennis, D.M. Pluronic microemulsions as nanoreservoirs for extraction of bupivacaine from normal saline. J. Am. Chem. Soc. 126, 5108-5112 (2004).

24. Napoli, A. Lyotropic behavior in water of amphiphilic ABA triblock copolymers based on poly(propylene sulfide) and poly(ethylene glycol). Langmuir. 18, 83248329 (2002).

25. Kawakami, H.; Ohse, T.; Kawano, M.; Nagaoka, S. Superoxide dismutase activity of a novel macromolecular manganese porphyrin. Polym. Adv. Tecnol. 10, 270274 (1999). 